\title{
Politicizing Power Between the Imperial Female and the Malay Other in Emily Innes's The Chersonese With The Gilding Off
}

\author{
Hanita Hanim bt Ismail (Corresponding author) \\ The Department of Human Sciences, International Islamic University, Malaysia, Malaysia \\ Wan Roselezam Wan Yahya \\ Faculty of Modern Languages and Communication, Universiti Putra Malaysia, Malaysia
}

Received: 06-03-2016

doi:10.7575/aiac.ijclts.v.4n.3p.11
Accepted: 13-05-2016

Published: 01-07-2016

URL: http://dx.doi.org/10.7575/aiac.ijclts.v.4n.3p.11

\begin{abstract}
The autobiographical writing by Emily Innes's The Chersonese with the Gliding offer corded experiences and turbulence underwent by a White officer's wife to Malaya with an underlying western perspectives and impression on the country during pre-Independence period and its people. By using narrative data, this article examines existing power relations, framed within interactions between the white lady (representing the Self) and her Malay male servants (as the Other). The use of Michel Foucault's Technology of Power enables an analysis of power strategies that represent both binary opposites in order to also trace the existence of gender power. More specifically, it allows a protoconceptualisation of types among Malay men that are identifiable during the pre-Independence period. Further understanding the Malay men, especially of their ego, is important in the growing interest over Postcolonial subject where it explores forms of resistance, portrayed by the Other in his daily power relation with the Self. Findings reveal that while power play exists within these interactions, it is a one-sided discourse which sanctions fair play as well as equality of power distribution.
\end{abstract}

Keywords: Malaya, Foucault's Technologies of Power, Masculinity, Malay Man's Ego, Malayness

\section{Introduction}

Malaysia or once known as Malaya, was colonized by many modern superpowers but it is the English empire which occupied the nation the shortest, making it one of its commonwealth. Yet, it is within this short period of colonization where the empire maintained its colonisation in subtle forms, including those employed by civilians like the housewife/traveller Emily Innes. Like other Victorian female travellers to Malaya, she recorded her (mis)fortunate travelogue in The Chersonese with the Gilding Off (1885), which compiles stories of her humble stay and routines in the muddy Langat in two volumes. Her journey into the world of the Other began when she followed her husband for an administrative post as a second-ranking "collector and magistrate at Langat, in the Malay native States" in 1885 decades after the Portuguese and Dutch occupation in the country (The Chersonese, Vol. 1, p. 1). Her travelogue includes several interactions with local authorities and natives in Innes's attempt to settle down in Langat.

Past criticisms on The Golden Chersonese associated it with colonial discourse theories where some in particular traced the relationship between the white Empirical Self and the Other. Doris Jedamski (1995), for instance, differentiated female Victorian travellers from those of the early twentieth century in term of purpose in writing, which Anderson (2008) saw the former's act as a form of liberation. Jedamski explained that these Victorian female travellers' writings are acts of self-proofing, where they validated their existence and capacity to travel beyond their safe haven, besides achieving a form of recovery from "physical and psychological unease", where their homeland put a limit to, unlike the latter type of travel writing (p. 21). Jedamski also observed that travelling allowed them to form opinions of the Other where the object is often either romanticised or turned into a focus of savagery, including Innes, who viewed that "any illusions ... or positive projections on the Other" as a "need to degrade and humiliate [them] in order to maintain a minimum of self-esteem" (p. 38). This suggests a retrospection on power play, making it an interesting angle to explore further. Maintaining self-esteem, in Innes's case, is an example of power possession and she uses a variety of Technologies of Power (TP) are used in order to maintain her possession of power. Hence, Innes' writings exemplify an act of turning the Other into savage objects that are non-comparable according to the English standards and conception of Beauty. Issues of power within this novel was also addressed by FarishNoor (1997) where he also paid attention on identifying whiteness, which distinguishes the Self from the Other. Yet, Noor (1997) did not dedicate attention on analysing power discourse in association with masculinity, which this paper is excited to draw upon. Of course, there are other scholastic concerns with regards to The Golden Chersonese, such as the created image of the Self as saviours (Ahmad, Pillai \&Yusof 2011) to issues regarding masculine portrayals that suited the colonial period (Hull \&Mohd Pakri 2015).

In another writing, Sara Mills (1991) proposed that Innes forwarded a new form of counter-hegemonic writing within a colonial discourse. Mills viewed a distinction in writing styles between the genders where “women's colonial writing 
was appreciably different from that produced by men" (p. 3). The former opted to write on more private spheres such as "describing their relationships with individual members of the colonised societies" instead of employing an "authoritative, imperialistic narrative voice". This provides an outlet of expression against the repression instilled by the patriarchal mainstream. Christine Doran (1998), however, saw the absurdity of this proposition. Doran insisted that despite Innes' constant complaints against the supportive Government during her stay at the swamp, she was like Isabella L. Bird who "maintained a serene conviction about the merits and morality of British imperial rule" (p. 177). The only problem that weakens the arguments between Mills and Doran is a nagging curiosity on the superiority of a female Imperial traveller, depicted by Innes, over the natives which also spurred the interest of this paper. There is an earlier paper which also drew upon similar focus on understanding the interaction between the colonized and the colonizer by using Edward Said's concept of the self and the other, yet it paid due attention to a different literary text (Al-Ogaili\& Babaee 2016). Doran listed various forms of responses produced by the colonised in response to Innes's authority, her observations are general in manner. The act of "disobedience", "disregarding ... orders", "insolence" and "lying [in order] to manipulate" observed, are generalised on the three natives - the Malay, the Chinese and the Indian objects (p. 184-185).A study on specific interactions between the female Imperial and the Malay native, hence, remains absent. This paper, thus, problematizes Innes's perception of Taip as one of the Malay male as a form of power assertion and examines the level of resistance on his part in reclaiming power in their discourse exchange.

This paper, therefore, aims to examine the depiction of power relations between the female Imperial and the colonised Malays in Inness's The Chersonese, discussing intensely on the issues of power. Its main focus is to analyse the use of power strategies in the Self's use of hegemony onto the Other by further studying the ownership of power within the discourse. Although Innes is the sole narrator of the travelogue, several other questions proceed which is to find out whether she has successfully exercise a hegemonic discourse and if so, has the "unheard voices" of the Other prevail against the female Imperial in their counter-discourse. Therefore, that names the second intention of the examination of this paper. Finally, this paper also intends to investigate the correlation between the success within a hegemonic discourse and the ingrained ego, possessed by the Malay male natives.

\section{Analysing Technologies of Power in a Self/Other relationship and the Formation of Malay Male Ego (MME)}

Power, as according to social sciences and political studies, is defined to be an ability to inflict influence onto others in order to obtain a certain impact. While power is defined and continuously theorised by many (e.g. Hobbes 1651), there is a clear opposing theories on the state of its permanence/fluidity. On one hand, Weber (1922) perceived power as permanently-owned while Foucault (1997) viewed it as an entity that situates its existence in a capillary network, needing a continuous effort of establishing itself as well as expecting resistance in its handling (Duineveld \& Guus 2011).

This constant need for power (re)negotiation is seen in The Chersonese where power is in flux, needing for questioning, re-examining and contesting over its relevance and possession. The depiction of Innes's constant contestation for power ownership when dealing with the locals who serve her emphasizes on this element. Her reporting in the travelogue, for instance, is a reinstatement for power after contestation, despite her earlier assessment of the locals as nothing lesser than "civil and obliging" (Vol. 1, p. 6).Her monologues often reminds the readers of the insufficiency of a nation that lacks civility.

Such contestation of power is also asserted while evaluating the local females' appearance and manners: "she was frowzy in her garments and very dirty in her habits; she chewed betel constantly, and her talk required Bowlerizing so much that I soon pretended to know no Malay, and thus to silence her" (Vol. 1, p. 11). As if indicating that by allowing speech by the Other, Innes loses her prominence in presence as what is highlighted by Sergui Balan (2010) who added on, the function of power as a form of strategy, instead of possession. Inness's attempt of silencing the Other works on strategy that pretending not to know the language is a politer manner of stopping the discourse. This is exactly what highlighted in the need to continuously renew power since it is "dynamic" in nature $(1980 ; 1982)$ where resistance is a part of the whole process of owning power. Both power possession and resistance co-exist as a singular entity. As such, the effort to reinstate power can take up in forms of negotiation, reminders and even coercion. These are other examples of Foucault's TP, besides those that are suggested in the umbrella of bio-power, allowing the exploration of power possession is also observed through confession and examination.

Yet again, examining power in the interactions between Innes and the locals calls for a prior understanding on Malays as a whole. The earliest conceptual definitions of the Malays were firstly formed by the foreigners, who either lived among the subject as "monks, civil servants, planters, sailors, soldiers, popular travel writers and tourist" (Al-Attas, 1977: p. 112). Some of these foreigners who Syed Hussein Al-Attas mentioned in his book are like Frank Sweetenham and Hugh Clifford. They were both British Residents in Malaya. Sir Thomas Raffles, who came in contact with the Malays in 1810, viewed the Malays of that period as not having been achieved the level of intellectuality, not forgetting the lack of civility (Al-Attas, p. 38). Shamsul A. B. (e.g. 2001) highlights the earlier acceptance of such definitions as needing for further problematization. Other observable writings on Malays are like Lewis Morgan, who identified the Malays as a group of people with great emphasis for kinship. All these early efforts of orientalising the Malays generally focused on qualities such as indolent and backward, if not community-emphasis. They were seen as lacking the esprit towards work. Hussein Al-Attas categorized this lacking into several sub-definitive aspects, explaining that the Malays were either seen as having "no love for work", "no will for work", "no energy or enthusiasm manifested during the understanding", "no concern for the outcome of the undertaking", "no concerns for the gain of the undertaking" and "no concern for the necessity which impels the undertaking" (p. 71). All these led to a singular 
percept of the Malays during that period which is lackadaisical manner of viewing colonial profit, to which is contestable in nature. Al-Attas explained that the oriental approach of conceptualising the Malays as an object of Inquiry is not scientific in manner. After all, these colonial travellers who wrote on Malays were not researchers per say. He argued that the Malays were assessed based on "faulty generalization" with the intention to fit an event based on "contextual meaning". Some perspectives were to an extent, contained "prejudice" and "lack empathy" towards the object of inquiry (p. 112). Al-Attas has earlier suggested that these foreigners' definition of the Malays were based on their colonial interest over capitalism because the Malays refused to cooperate in the colonial master plan to reap Malaya's harvest. He explained that it was the colonials' way of getting back at the Malays, "a veiled resentment against the Malay's unwillingness to become a tool for enriching colonial planters" (pp. 80-81).

Al-Attas later characterised the national character as owning the easiness in approaching life yet sensitive to mere insults, while having a great emphasis on loyalty for their leaders and kings. Religion was vital to them. They were profoundly polite creatures who "lack incentive or initiative for acquiring wealth", or at least afraid of taking risk (p. 115). Hence, this explains the many current effort of subsidising the Malays in the efforts of making them richer. Yet, Al-Attas reminded that money is not a total reason for their backwardness; it is "the poverty of their soul (kemiskinanjiwa)" that withheld the Malays (p. 148). This would include the sustainability of enduring hardship towards attaining prosperity and resilience. These discussions on Malay and Malayness are important at this point because it provides an understanding of the object of Inquiry that Innes is keen on to which she often overgeneralises and misconceives.

However, no scholar has yet discussed on the Malay Man's Ego, which is the primary reason for exploring the discourse between the Imperial West and the Malay Other. Unlike the psychological concept of ego, the Malay Man's Ego are visible in common Malay quotes like "death shall not come before it is destined" (berpantangmatisebelumajal) or "let customary comes first before the offspring" (biarmatianak, janganmatiadat), which validate the refusal to surrender and placing custom as a primary concern. Although the central idea might overlap on a distant understanding where like Freudian concept of ego, Malay Man's Ego focuses on acting what his community thinks of him, prioritizing his culture instead of others. The importance of observing and performing the Malay customs (adat) indirectly forms and elevates a Malay Man's Ego where there are aspects that require Malay women to adhere to in order to preserve such ego, for instance, not allowing another man into the house during the absence of her husband. J. Nagata provided an interesting discussion on Malays' generic-descriptive customs that are practised without any question. Of course, this obedience is part of the religious requirement, which prohibits fitnah (ill-thoughts) that might follow, if a woman permits another man to enter her house. A Malay Man's Ego distinguishes from the Indian's or Chinese, even the White Man's Ego in terms of his priority over cultural concerns.

\section{Tracing Hegemony and MME in Innes' The Chersonese}

In the travelogue, Innes is mostly without the company of her husband during their six-years of stay due to his frequent visits to areas within his recent assignment as a replacing officer. She has to run errands and manage the household on her own, including carrying out inevitable communications with several other Malay men. When she wrote that "the marriage laws of Malaya, like those of England, appear to have been made exclusively for the men and for the men's advantage, as they permit immense latitude to the husband and none to the wife in most cases" (Vol. 1: p. 85), this invites the investigation on the role of male ego in determining the success of the native's counter-hegemonic discourse against the female Imperial. In the case of this paper, there is a need to understand the exchange of difference that took place between the Other Malay male ego and a representation of female Imperial Self. This is because Malay men, in general, are assumed to have owned an ego when it concerns women, especially one who is with power like Innes.

This travelogue offers a perfect setting for inquiry on the collision of power between a female Imperial figure and a Native Malay whose ego might deter the initial assumption of authority in the text. Although Innes's analyses of the Malay specimen include both genders, her preferred interaction leans towards the male counterpart. To her, the Malay women are generally seen as lacking grace in their conduct with little sense of dignity and self-preserve - a point of allowing fraternization with married men till late hours.

Throughout her interactions with the Malay men, Innes concurs on the common perception of their indolence and insolence which are redundant in most Imperial observations. To her, they are "semi-civilised", in fact "treacherous Mohammedans" (Vol. 2: p. 1). Earlier, she expresses her observations on the Malays as the "laziest being on the face of the earth" (1: p.187). Her construction of the Malay men as indolent and insolent is further reinforced in her interactions with Taip the cook. His insolence is problematized through two parameters - the concept of punctuality and aptness in servitude.

Taip is a perfect depiction of the Malays who fits the purpose of this paper in order to exhibit power collation and resistance. He is not the only Malay male character that Innes comes in contact. In fact, there are others, including the policemen who she refers to as the "Jaga", the servant boys as well as the royalties (such as Tunku Diauddin,Tunku Muda, etc.). Yet, Taip is sufficiently recognized of his subordinating existence as well as him being empowered to refuse Innes's residential management (in one way or another). As such, Taip's resistance as a Malay Male Ego against Innes, the female Imperial master represent the best depiction of the Self against the Other. These representative acts are his reactions when instructed to prepare ham for dinner and his efforts to alter the Western epistemology.

Of the two acts, the clash of ideology between the female Imperial persona's demeaning percept of the Natives and the Malay Male Ego is most apparent through Taip's refusal to immediately execute the task when he is summoned to 
prepare ham for dinner. During her solitude stay as a housewife whose husband is given an acting post in Klang, she is without anyone to communicate with, except with her Malays subordinates and this leaves her the "dreariest time" during her stay in Langat (Vol. 1: p. 211). Innes highlights his delay as an embarrassment before an invited guest and anxiety on her part. Taip, on the hand, sees the misappropriation of preparing ham as due to his religious beliefs touching ham is haram in Islam, hence he has to wait for Apat the Chinese cook to assist him. However, she points out his inconsistency at upholding his religious stance and issues of haram where she quotes on his lackadaisical approach concerning religious forbiddance when it comes to drinking brandy during the festivity. The Inneses have to entertain guests during Hari Raya and New Year by throwing parties in return of gifts received (Vol. 1: p. 224). Earlier, she explains to the readers that Taip sees no difficulties at handling ham, pointing out his "throwing [away] his religion and his country" for the sake of "fortunes" and that religion is secondary (Vol. 1: p. 222). Her argument suggests innuendos of his intentional tardiness and that it is "his pride [that] prevented his turning over a new leaf in our home" (Vol. 1: p. 229). A recurring event involving handling ham is when Taip fails to dispose a plate of lard fat, causing "a natural consequence swarming with ants" (Vol. 1: p. 228). He uses the same excuse of religious forbiddance in substantiating his delay in executing the command, hoping Apat to deal with this. Ergo, it is within these two incidents, Innes constructs an understanding of the Malays through a perfect specimen - Taip the cook. To her, his wayward behaviour builds a summative impression of the Malays who are incapable of hard work, obedience and keeping clean.

In both incidents, Innes exhibits clear power play in her managing Taip as a servant-man. She reiterates her superiority firstly by assessing the event that shapes her conceptualisation of the Malay identity based on the Western ideas of civilized conducts, including those concerning punctuality. In such cases, she identifies his defiance of the Western concept of time-importance through his casual reaction to prepare dinner for an important guest to the Inneses' home. Upon this assessment, one sees a pattern of Foucault's concept of power examination when Innes confronts Taip for an explanation in order to further understand him, which is followed by his defence. However, since the travelogue is narrated by Innes, she finalises the argument by narrating a conclusive observation on Taip's application of the rules of haram. Indirectly, she is confessing her superiority over his silent insufficiency, which provides us an example of Innes using technologies of power in order to assert her version of power. Both examination and confession illustrate the workings of Innes's bio-power.

As a participant of the incidents, Innes presides an epistemological location through her narrative that enables her to continuously assess the Malays and their values as well as their ethics, believing that her way of looking at the world is the ideal practice. In fact, her superior tone initiates from the beginning of the travelogue as she sees her husband's post as "superior to the two others in the same State" (Vol. 1: p. 2), yet highlights the failure to achieve proper recognition unless proper reprimand is given. She views her husband's new post in Langat as an extension of a "branch of the English Government" (Vol. 1: p. 3), making her part of the Greater Empire. Yet, this superiority in position is often forgotten as she writes, her husband is "too modest to assert our rightful claim" (Vol. 1:p. 210). Her assessment of the Other is active and constant, which is in line with Foucault's concept of power where it requires constant examination and confession. Taip is perceived as different based what she sees fits the world and this is what Holquist described as the making "sense of existence" where:

We perceive the world through the time/space of the self and through the time/ space of the other. The difference between the two is a relation of otherness that can be gauged by differing positions of outsideness that are enacted as varying degrees of trangredience.(p. 35)

Identifying Taip's incapacity to conform to the Western epistemological practices leaves her to draw acute observation on the Malays; her encounters with them are incomparable to those from mutual civilization (Vol. 1: p. 211). Although she sounds rather summative and biased (Said 1979) in her analyses, her observation forms an equivocal comprehension over the Malays as savages and thus, subordinates them in order to reinforce an Imperial identity. At one point, Innes even correlates the incident of Taip's leaving the lard dry in the pantry with the prophet and his Muslim followers' incapability to maintain cleanliness, issuing that "their dwellings were permanently surrounded by nastiness" (Vol. 1: p. 229). Even her general observations on the Malays' laziness is quickly correlated to their religion, declaring that Islam forbids the counting of age and this is the making of their unpunctuality. This shows her lack of resourcefulness at truly understanding the community. This is another example of the West's orientalising the Orient. By placing a binary opposition between West/East, identifying beauty/savage and naming normal/abnormal, definitions over a variety of matters are created. In the power exchange between Innes and Taip, concepts of punctuality and cleanliness differ and this problematizes a possible singular way of looking at the world.

Instead of accepting the Imperial practice of managing the world, Taip depicts several examples of 'voicing back' against the Imperial master by consistently drawing a line between what is permissible and otherwise, as accordance to Islam. His resistance to Innes's command at handling the ham is an act of reclaiming power, which is made possible through his strong religious conviction. Since Malayness is partially defined based on the embrace of Islam as a religion, obeying proper Islamic conduct would include intentional contact with objects that are considered as haram. An important feature that distinguishes a Malay from other racial entities in the country is the ethnic's ability to converse in Bahasa Melayu, which qualifies them having sufficient attributes of Malayness. His defiance is shown through the act of delaying the execution of task, making it among his several forms of resistance when dealing with Innes as the Master. Besides delay, Taip remains silent or sulks as forms of resistance, which are some of the conducts that Doran (1998) saw as identifiable in most Post-colonial figures. It is interesting to observe zero application of violence through his resistance. Instead of using abusive words or physical contact to show resistance, Taip stands at 
par with Innes in terms of civility and manners. He is calculative in his resisting movement, making him an almostgentleman. This is because hastiness is cautioned against in Islam as it is part of the Devil's characteristics.

In another interpretation, Taip's refusal to obey Innes's command of handling the ham can be associated to his perception towards women. She observes his reluctance to obey her command, those given out by her husband claiming that "the masculine gender is more worthy than the feminine" (Vol. 1: p. 222). She reiterates that his disobedience occurs "nine times out of ten" (Vol. 1: p. 223). This is because before Mr. Innes's appointment as an acting Resident in Klang, Taip was in charge of manning the wine and spirits and he refused any form of interference from his lady master. To him, such "petticoat government" should not be paid attention to, like those voiced out by his wife, when he left her to join Mr. Innes in service, which explains the display of his Malay Man's Ego (Vol. 1: p. 223).

Taip transcends beyond resistance by imposing his definition of right and wrong upon the master. This is a clear imposition of power onto the Self by the Other as he sees himself as fit to suggest a possible use of the vase as a drinking vessel, instead of using the champagne glass. However, Innes categorises this as an act of "improper ingenious" (1: p. 226). A Malay man such as Taip, who has never seen a wine glass, might admire its tall stem as a beautiful vase to display flowers as a centrepiece. To him, drinks are commonly served in 'gelok air' (mug-like drinking vessels which is made of clay), hence providing us an example of innovation where he transforms a onepurpose item into what he is most familiar with - the familiarity of a vase-like drinking vessel. Besides, the appreciation of flowers run across culture where Malay families also would let flowers bloom in their yard. Yet, this is counterargued by Innes, declaring that Taip's insistence to use such the glass and vase for the wrong purpose is not because of his ignorance but wishing for some "variation" (Vol. 1: p. 227).

Innes, on the other hand, upholds the singular Western way of using such objects - glasses are for wine, while vases are for the flowers. She resides within a spatial location that specifically names such items to own such purpose and when Taip challenges her orders, he distorts her singular perception of things in the world. By doing so, he challenges the rigidity that West enforces upon the Orients, offering an alternative to the co-existing power. In fact, her refusing to acknowledge of a possible alternative to such naming earns her a label. By believing that her way of looking at the world is the correct way, she reasserts herself over a totalitarian approach of world percept.

In such cases, it is not Taip's manliness that empowers him the ability to 'voice back'; he is given the invincibility to challenge her percept through his religious convictions. He refuses to see his religious epistemology as wrong since he is convinced that his Islamic and Malay culture is sufficient to view the world to a point it becomes a genericdescriptive reaction for his refusal to prepare the ham for dinner. Her percept on using the wine glass as a decorative ornament is valid yet, preparing the ham for dinner limits his capacity as a helper since he is forbidden to prepare the ham alike any other Malays as dictum by Islam. Despite of his long-standing service with the Inneses and his steady contribution towards her well-being and efficacy in her domestic management during her husband's service elsewhere, he draws the line of compromise when her orders contradicts with the Islamic teachings. This silence is a strong refusal that voices his beliefs and reinforces his Malay Man Ego, which Innes denies to acknowledge. Like the many cultural practices seen as "absurd", her narrative refuses to recognize Taip's religious boundaries since it involves her image as an Imperial Master, failing to discipline her man-servant.

Reading this text in first sitting might cause one to feel enthralled with the possibility of a challenger in the Self/Other power-relation. In several opportunities, Taip is able to manifest a challenge against the powerful imperial master, as represented by Innes. However, the reading of the text unravel new findings about the power of culture against a totalitarian kingdom - the West since the narrative is mainly authored by the Self, refusing an omniscient point of view. Taip's other reactions are silenced, making this travelogue ill-fitted in the norms of novel-writing.

In order to enable power assertion, it requires an operational bio-power which includes constant examination and confession within both selves. For Innes, Taip is seen as failing to conform to the presumed civilized conducts. Taip, on the other hand, sees her domineering role as a woman which he chooses to ignore since it is upheld within public sphere. To him, she is another petty woman like other Malay women. In the end, both selves do not own truth in its location; they are true within each other's location of space and time. Innes, for instance, possesses truth based on her spatial and time location; wine in a champagne glass and flowers in a vase are common to the Western culture. Hence, when she is given an unconventional way of presenting the objects, she criticises such choices in a pejorative manner. Thus, in any power talk (such as one between Innes and Taip), the one in power of defining truth will have the tendency to demean the other in order to retain strength within its claim.

\section{Conclusion}

Taip's contestation of power against Inness shows a depiction of discourse between the Self and the Other in a setting that positions her Imperial authority. This friction can also be read as Taip's form of establishing his masculinity against the white woman, creating layers of understanding for a Malay Man's Ego. His persistence at proving his dominance in his expertise of cooking causes more questions in Innes which is finally reported to side on her since it is her narration. Although her travelogue is narrated in witty manner, it depicts silent belittlement of the locals, including the Malay men which reiterates her perception of the Other and their world. Her perception of the world is based on the more civilised nation, making the Other incompatible for any means of equal respect. Despite this expressed standard of living, her orientation is constantly questioned through Taip who is bold to contest her superiority in colour and that establishes an understanding of a Malay Man's Ego. The Malay men are too proud to take subordinating commands, especially ones with regards his area of expertise. 
References

Ahmad, S. N., Pillai, S., \& Yusof, N. M. (2011). "Rehabilitating Eden: archetypal images of Malaya in European travel writing". Journeys, 12(1): pp.22-45.

Al_Ogaili, T. A. J. \& Ruzbeh, B. “Ambivalent Colonial Relations inOctavia Butler's Wild Seed”. International Journal of Human Sciences, 13(1) Jan 2016: 22-31.

Anderson, C. (2008) On the Contrary: Counter-Narratives of British Women Travellers, 1882-1885.Doctoral Thesis. University of Western Australia.

Balan, S. “M. Foucault's View on Power Relation”. Cogito- Multidisciplinary Research Journal, 2(1): pp. 193-198.

Clifford, M. L. (1968). The Land and People of Malaysia. Philadelphia \&New York.

Doran, C. (1998). “Golden Marvels and Gilded Monsters: Two Women’s Accounts of Colonial Malaya”. Asian Studies Review, 22(2), pp. 184-185.

Duineveld, M. \& Dix, G. (2011). "Power and Discipline in Transitions: Michel Foucault." Ed. SietzeVellema. Transformation and Sustainability in Agriculture. Wageningen Academic Publishers.

Foucault, M. (1980). Power/Knowledge: Selected Interviews and Other Writings 1972-1977, Ed. Colin Gordon, New York \& London.

-- (1982). “The Subject and Power". Critical Inquiry,8(4), pp. 777-795. Hall, S. (1964). A History of South East Asia. 2nd ed. London

Hobbes, T. (1651). Levianthan, Or The Matter, Forme, \& Power of a Commonwealth Ecclesiasticall and Civill. Andrew Crooke: London.

Holquist, M. (1990). Dialogism: Bakhtin and his World. $2^{\text {nd }}$ ed. Routledge: London \& New York.

Hull, S. P., \&MohdPakri, M. R. (2015). “A colonial by acquisition: ambivalent subjectivity in Agnes Keith's Land Below the Wind." Studies in Travel Writing, 19(4): pp. 371-399.

Jedamski, D. (1995). Images, Self-Images and the Perception of the Other: Women Travellers in the Malay Archipelago. Occasional Paper No. 26. Uni. of Hull: Hull, 1995.

Lewandorski, J. (1995). "Rethinking Power and Subjectivity after Foucault". Symplokē, 3(2):pp. 213-243

Mills, S. (1991). Discourses of Difference: An Analysis of Women's Travel Writing and Colonialism. London: Routledge.

Nagata, J. (1974). "Adat in the city: Some perceptions and practices among urban Malays". Bijdragen tot de Taal-, Land- enVolkenkunde, 130(1), pp. 91-109.

Noor, F. A. (1997). "Innocents abroad? The erasure of the question of race and power in contemporary feminist and 'nostalgic' travelogues.” South East Asia Research: pp. 57-88.

Said, E. (1979).Orientalism, New York.

Shamsul A.B. (2001). “A History of an Identity, an Identity of a History: The Idea and Practice of 'Malayness' in Malaysia Reconsidered”. Journal of Southeast Asian Studies, 32(3), pp. 355-366. 